\title{
A STUDY ON PHYTOCHEMICAL SCREENING, ANTIOXIDANT, ANTIMICROBIAL AND $\alpha$-AMYLASE INHIBITORY ACTIVITIES OF CRUDE EXTRACTS OF THE STEM BARK OF PISONIA GRANDIS, R.BR
}

\author{
VISHU MOHAN ${ }^{1}$, MOHANKUMAR RAMASAMY ${ }^{2}$, SRIKALYANI VEMURI ${ }^{2}$, ILANGO KALIAPPAN ${ }^{1,2 *}$
}

${ }^{1}$ Department of Pharmaceutical Chemistry, SRM College of Pharmacy, SRM University, Kattankulathur - 603 203, Kanchipuram, Tamil Nadu, India. ${ }^{2}$ Division of Phytochemistry and Pharmacognosy, Interdisciplinary Institute of Indian System of Medicine (IIISM), SRM University, Kattankulathur - 603 203, Kanchipuram, Tamil Nadu, India. Email: ilangok67@gmail.com

Received: 05 June 2017, Revised and Accepted: 19 July 2017

\section{ABSTRACT}

Objective: The aim of the present study is to determine the phytochemical screening, antioxidant activity and $\alpha$-amylase inhibitory activity of the crude hexane, ethyl acetate and ethanolic stem bark extract of Pisonia grandis.

Methods: The evaluation of antioxidant and antimicrobial activity, total phenolic, and flavonoid content were assessed using 2,2-diphenyl-1picrylhydrazyl, Folin-Ciocalteu's reagent, and aluminum chloride assay, respectively. The antidiabetic activity was assessed for porcine pancreatic $\alpha$-amylase for the stem bark of P. grandis.

Results: Phytochemical screening confirmed the presence of phenolic, flavonoids, tannins, saponins, terpenoids, and steroids in all the three extracts. The antioxidant activity showed $148.2 \mu \mathrm{g} / \mathrm{ml}$, total phenolic content (gallic acid equivalent), $0.0665 \pm 0.0002 \mathrm{mg} / \mathrm{g}$, flavonoid content (quercetin equivalent), $0.6061 \pm 0.1817 \mathrm{mg} / \mathrm{g}$, and inhibitory concentration $50 \%$ values were found to be $40.42 \mu \mathrm{g} / \mathrm{ml}$ and showed better in ethyl acetate extract. The antidiabetic activity exhibited mimic action with insulin due to the presence of pinnatol in the stem bark and leaves of P. grandis.

Conclusion: P. grandis stem bark crude ethyl acetate extract showed strong antioxidant activity, high phenolic, and flavonoid content. The antimicrobial activity was studied in both Gram-positive and Gram-negative strains against ampicillin and rifampicin as reference drugs. Antidiabetic activity shows effective result by $\alpha$-amylase inhibitory activity.

Keywords: Pisonia grandis, Antioxidant, Antimicrobial, $\alpha$-amylase, Total phenolic content, Total flavonoid content, Plant extract.

(c) 2017 The Authors. Published by Innovare Academic Sciences Pvt Ltd. This is an open access article under the CC BY license (http://creativecommons. org/licenses/by/4. 0/) DOI: http://dx.doi.org/10.22159/ajpcr.2017.v10i11.20447

\section{INTRODUCTION}

Pisonia is a genus of a flowering plants of family Nyctaginaceae. P. brunoniana of Australasia and Polynesia and P. umbellifera, which is widespread in the tropical Indo-Pacific region [1], belongs to the same species. Pisonia grandis has been extensively used in Indian traditional medicine as an antidiabetic, anti-inflammatory agent, and used in the treatment of analgesic, ulcer, dysentery, and snake bite.

As Ayurvedic literature reveals that P.grandis has tremendous traditional and medicinal uses including analgesic, anti-inflammatory, and diuretic activities [2], has a protective wound healing potential on Wistar rats excision wound and incision wound and antibacterial activity [3], possess antifungal activity against various microorganisms [4], antidiabetic activity [5], anxiolytic activity in mice [6] was studied, antioxidant activity [7,8], antiplasmodial activity [9], antipyretic activity [10], hepatoprotective [11], anti-arthritic activity [12], used in the treatment of analgesic, ulcer, dysentery and snake bite [13,14], anorexia, jaundice [15], and various high performance thin layer chromatography fingerprinting analysis were performed and reported $[16,17]$.

In this study, we investigated the phytochemical and biological screening of $P$. grandis stem bark for the crude extracts. The novelty of the method includes the $\alpha$-amylase inhibitory activity of pinnatol which helps in the inhibition of the $\alpha$-amylase from the stem bark of $P$. grandis using pancreatic $\alpha$-amylase enzyme $[18,19]$. Apart from this the antioxidant and the antimicrobial assay were also performed.

\section{METHODS}

Chemicals

The chemicals used in the present study were sodium nitroprusside, sulfanilic acid, phosphate buffer saline (pH 7.4), Naphthyl - N-ethylene diamine, phosphoric acid, dimethyl sulfoxide, ascorbic acid, $\alpha$-amylase potato starch, sodium chloride, silver nitrate, sodium potassium tartrate, sodium hydroxide, 3, 5-dinitro salicylic acid, and acarose. All the chemicals utilized were of AR grade.

\section{Collection and authentication of plant}

The plant was collected in and around SRM University, Kattankulathur campus and authenticated by Dr. P Jayaraman, Director, Plant Anatomy Research Centre Medicinal Plants Research Unit, Tambaram, and Chennai - 45.

\section{Chemical constituents}

P. grandis has numerous bioactive compounds includes pinnatol, allantoin, $\beta$-sitosterol, $\alpha$-spinasterol, $\beta$-sitosterol glucoside, octacosanol, dulcitol, flavonoids, and quercetin the major chemical constituents were shown in Fig. 1. These are the compounds which have been isolated from the leaves of the plant [20].

\section{Preparation of plant extraction}

Coarsely powdered the stem bark of $P$. grandis procured was extracted successively with various solvents ranging from nonpolar to polar, i.e., n-hexane, ethyl acetate, and ethanol using cold maceration method and the respective solvents were recovered under rotary evaporator. In each solvent, the plant material was soaked for $72 \mathrm{hrs}$ at $30 \pm 2^{\circ} \mathrm{C}$, 
filtered and to the residue, the same solvent was added and repeated thrice to become colorless. All the filtrates were pooled, and solvent was removed in a rotary evaporator under vacuum.

\section{Physiochemical evaluation}

Ash values, extractive values and foaming index were determined according to the WHO guidelines and moisture content was determined by drying at $105^{\circ} \mathrm{C}$ until a constant weight was achieved.

The physiochemical parameters such as total ash, acid insoluble ash, and water soluble ash were performed as per the standard method [20]. The extractive value determines the actual percentage of active constituents extracted using solvents from a specified amount of plant extract and the alcohol extractive value, water soluble extractive, loss on drying, and foaming index were performed, and the results were tabulated in Table 1

\section{Preliminary phytochemical screening}

Phytochemical analysis [21] was performed as per the standard methods for the presence of alkaloids, reducing sugars, glycosides, saponins, phytosterols, phenols, tannins, flavonoids, resins, and starch.

\section{Determination of phenolic content}

The content of total phenolic compounds in plant extracts was determined by Folin-Ciocalteu's reagent using ultraviolet (UV) spectrophotometer (UV-1501PC) [22]. $0.5 \mathrm{ml}$ of diluted plant extract and standard of different concentrations solution were taken in the test tube followed by adding $5 \mathrm{ml}$ of Folin-Ciocalteu's (diluted 10fold with water) and $4 \mathrm{ml}$ of sodium carbonate (1 M), respectively. Solutions were then incubated for 15 minutes and protected from sunlight. The absorbance was measured at $765 \mathrm{~nm}$. Calibration curve of gallic acid was set using a different concentration of $25,50,100$, and $200 \mu \mathrm{g} / \mathrm{ml}$. The extracts were calculated according to the following formula:

\section{$\mathrm{T}=(\mathrm{c} \times \mathrm{V}) / \mathrm{m}$}

Where, $\mathrm{T}$ is the total content of phenolic compounds in $\mathrm{mg} / \mathrm{g}$ plant extract; $c$ is the concentration of gallic acid established from the calibration curve in $\mathrm{mg} / \mathrm{ml}$; $\mathrm{V}$ is the volume of extract in $\mathrm{ml}$, and $\mathrm{m}=$ the weight of extract in $\mathrm{g}$. The value of total content of phenolic compounds is expressed as gallic acid equivalent (GAE) in $\mathrm{mg} / \mathrm{g}$ extract [23].

\section{Determination of flavonoid content}

Total flavonoid in the crude extract was measured using the aluminum chloride colorimetric assay [24]. To $1 \mathrm{ml}$ of plant extract or standard of different concentrations $3 \mathrm{ml}$ methanol, $0.2 \mathrm{ml}$ of $10 \%$ aluminum chloride, $0.2 \mathrm{ml}$ potassium acetate $(1 \mathrm{M})$, and $5.6 \mathrm{ml}$ of distilled water were added. Then, the solution was incubated for 30 minutes at room temperature. The absorbance was measured at $415 \mathrm{~nm}$ against a blank. Standard curve was prepared using quercetin by dissolving it in methanol followed by serial dilution to $25,50,100$, and $200 \mu \mathrm{g} / \mathrm{ml}$.

\section{Biological activity}

Antioxidant assay

Antioxidant activity [25] of the extracts was performed using method 2,2-diphenyl-1-picrylhydrazyl (DPPH) scavenging [26,27]. $1 \mathrm{ml}$ of $0.1 \mathrm{mM}$ solution of DPPH in methanol was added to $3 \mathrm{ml}$ of the solution of all the extracts in ethanol at different concentrations $(5,20,40,60$,
80 , and $100 \mu \mathrm{g} / \mathrm{ml}$ ). The mixtures were shaken and were allowed to stand in dark room for $1 / 2 \mathrm{hr}$. Then, the absorbance was measured at $517 \mathrm{~nm}$ using UV spectrophotometer. Finally, scavenging capability of DPPH radical was determined by the formula:

Scavenging effect $=\left[\left(\mathrm{A}_{0}-\mathrm{c}_{1}\right) / \mathrm{A}_{0}\right] \times 100$

Where, $\mathrm{A}_{0}$ is the absorbance of the control

$A_{1}$ is the absorbance in the presence of all of the extract samples.

\section{Nitric oxide scavenging method}

The samples were treated with Griess reagent, and optical densities of the resultant chromophores were determined at $546 \mathrm{~nm}$. Among the three extracts tested for stem bark of plant, ethyl acetate extract of $P$. grandis has shown high potent antioxidant activity with inhibitory concentration $50 \%\left(\mathrm{IC}_{50}\right.$ ) value of $200.9 \mu \mathrm{g} / \mathrm{ml}$.

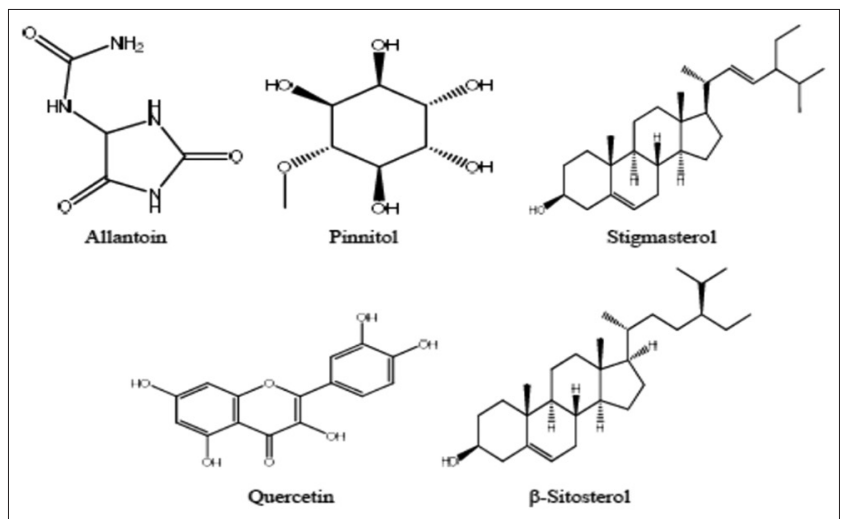

Fig. 1: Major chemical constituents of the leaves of plant

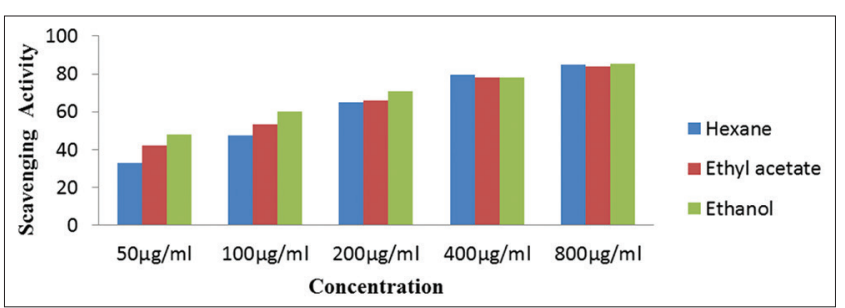

Fig. 2: Antioxidant activity of Pisonia grandis by 2,2-diphenyl-1picrylhydrazyl radical scavenging method

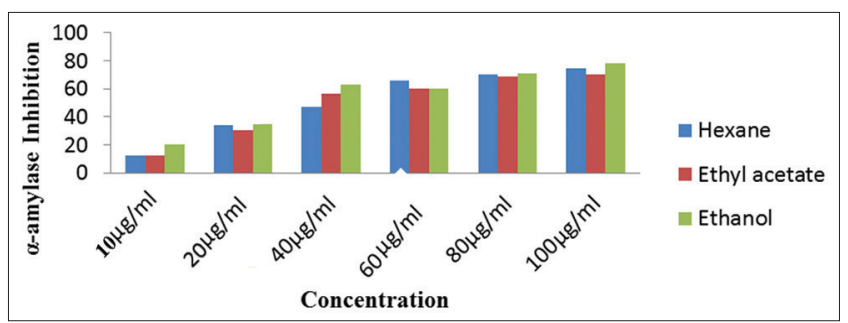

Fig. 3: Antidiabetic activity of Pisonia grandis by $\alpha$-amylase inhibitory activity method

Table 1: Physicochemical parameters of P. grandis

\begin{tabular}{|c|c|c|c|c|c|c|c|}
\hline \multirow[t]{2}{*}{ Plant name } & \multicolumn{3}{|c|}{ Ash value $\% \mathrm{w} / \mathrm{w}$} & \multicolumn{2}{|c|}{ Extractive value $\% \mathrm{w} / \mathrm{w}$} & \multirow[t]{2}{*}{ Foaming index } & \multirow[t]{2}{*}{ Loss on drying $\% w / w$} \\
\hline & Total ash & $\begin{array}{l}\text { Acid insoluble } \\
\text { ash }\end{array}$ & $\begin{array}{l}\text { Water soluble } \\
\text { ash }\end{array}$ & Water soluble & Alcohol soluble & & \\
\hline P. grandis & 14.5 & 11.5 & 4.5 & 24.0 & 16.0 & 111.11 & 10.0 \\
\hline
\end{tabular}


Antimicrobial activity

As the leaves of the plant possess antimicrobial potency, the stem bark was screened for antimicrobial activity [25,28]. Four microbes, i.e., Gram-positive bacteria such as Staphylococcus aureus and Bacillus subtilis while Gram-negative Escherichia coli and Klebsiella pneumoniae were used. Ampicillin (for Gram-positive) and tetracycline (for Gramnegative) were used as a standard.

\section{$\alpha$-amylase inhibitory activity}

The plant extracts were screened for $\alpha$-amylase inhibitory activity [29] at different concentrations using the chromogenic method from Sigma-Aldrich. Porcine pancreatic $\alpha$-amylase (EC 3.2.1.1, Type VI, Sigma) was dissolved in ice-cold distilled water to give a concentration of $4 \mathrm{unit} / \mathrm{ml}$ solution. Potato starch $(0.5, \mathrm{w} / \mathrm{v})$ in $20 \mathrm{mM}$ phosphate buffer ( $\mathrm{pH}$ 6.9) containing $607 \mathrm{mM}$ sodium chloride, was used as a substrate solution. $\alpha$-amylase activity was determined by measuring the absorbance at $540 \mathrm{~nm}$.

\section{RESULTS AND DISCUSSION}

\section{Qualitative phytochemical analysis}

The extracts were subjected to preliminary phytochemical analysis, and the results were tabulated in Table 2 .

\section{Physicochemical properties}

Physicochemical evaluation like ash values, i.e., total ash value, acid insoluble ash, water soluble ash, and extractive values such as alcohol extractive value, and water extractive value were performed foaming index and loss on drying were found to be $111.11 \%$ and $10.0 \% \mathrm{w} / \mathrm{w}$, respectively.

\section{Antioxidant assay}

Estimation of total phenol content (TPC)

TPC of extracts of P. grandis was expressed in terms of GAE. Among the three extracts tested ethyl acetate extract has shown high TPC,

Table 2: Phytochemical analysis of stem bark of $P$. grandis

\begin{tabular}{llll}
\hline Phytoconstituents & Hexane & Ethyl acetate & Ethanol \\
\hline Carbohydrates & - & + & + \\
Proteins & - & + & - \\
Starch & - & + & + \\
Amino-acids & - & - & + \\
Steroids & + & + & + \\
Cardiac glycosides & - & + & + \\
Anthraquinone glycosides & - & - & - \\
Alkaloids & - & + & + \\
Flavonoids & - & + & + \\
Tannins & - & - & - \\
\hline
\end{tabular}

P. grandis: Pisonia grandis

Table 3: Total flavonoid and phenolic contents of Pisonia grandis

\begin{tabular}{lll}
\hline Extracts & $\begin{array}{l}\text { Total phenolic in } \\
\boldsymbol{\mu g} \text { of } * * \mathbf{G A E} / \mathbf{m g} \text { of } \\
\mathbf{d r i e d ~ m a s s}\end{array}$ & $\begin{array}{l}\text { Total flavonoid in } \boldsymbol{\mu g} \text { of } \\
+\mathbf{Q E} / \mathbf{m g} \text { of dried mass }\end{array}$ \\
\hline Hexane & $0.2926 \pm 0.0003$ & $0.0359 \pm 0.0001$ \\
Ethyl acetate & $0.6061 \pm 0.1817$ & $0.0665 \pm 0.0002$ \\
Ethanol & $0.1919 \pm 0.0003$ & $0.0215 \pm 2.9463$ \\
\hline
\end{tabular}

${ }^{* *}$ Quercetin equivalents, ${ }^{+}$Gallic acid equivalents, each value listed in the table is expressed as mean $\pm \mathrm{SD}(\mathrm{n}=3)$, P. grandis: Pisonia grandis, GAE: Gallic acid equivalents, QE: Quercetin equivalents
$0.6061 \pm 0.1817 \mathrm{mg} / \mathrm{g}$ of gallic acid. The phenolic content in various solvents decreases in the order of EtOAc > hexane > ethanol, and the results were depicted in Table 3 and the DPPH scavenging activity was shown in Fig. 2.

\section{Estimation of total flavonoid content (TFC)}

TFC of extracts of $P$. grandis was expressed in terms of quercetin equivalents. Among the three extracts tested ethyl acetate extract has shown high TPC, $0.0665 \pm 0.0002 \mathrm{mg} / \mathrm{g}$ of gallic acid. The phenolic content in various solvents decreases in the order of EtOAc > hexane > ethanol, and the results were depicted in Table 3.

\section{Antioxidant activity}

In vitro, antioxidant activity was performed by DPPH and nitric oxide radical scavenging methods, and the results were tabulated in Table 4.

\section{Antimicrobial activity}

Ethanol extract of the stem bark of $P$. grandis showed a high level of inhibition against $E$. coli with a value of $94 \mu \mathrm{g} / \mathrm{ml}$ and the results were depicted in Table 5 .

\section{$\alpha$-amylase inhibitory activity}

The plant claimed to have antidiabetic activity as the leaves contain pinnatol which mimic the action of insulin. Among the three extracts tested ethyl acetate extract of $P$. grandis has shown high potent antidiabetic activity with an $\mathrm{IC}_{50}$ value of $40.42 \mu \mathrm{g} / \mathrm{ml}$ the results were depicted in Table 6 and the $\alpha$-amylase inhibitory activity was represented in Fig. 3.

\section{DISCUSSION}

Phytochemical screening not only helps to reveal the constituents of the plant extracts and the one that predominates over the others but also is helpful in searching for bioactive agents those can be used in the synthesis of useful drugs. In this study, the hexane, ethyl acetate, and ethanolic extract of stem wood of $P$. grandis showed the dosedependent antioxidant activity. Further, the significant antioxidant activity can be due to the presence of phenols, flavonoids, tannins, polyphenols, and reducing sugars. We reported the $\mathrm{IC}_{50}$ value of hexane and ethanolic extract to be lower than that of ethyl acetate extract. This showed that the radical scavenging property is higher in ethyl acetate extract of $P$. grandis and the $\mathrm{IC}_{50}$ value was found to be $148.2 \mu \mathrm{g} / \mathrm{ml}$. The antimicrobial activity was studied against different bacterial strains against ampicillin and tetracycline as control, and the ethanolic extract of the stem bark showed greater inhibition. The minimum IC values were found to be $72 \mu \mathrm{g} / \mathrm{ml}$ for $S$. aureus and $83 \mu \mathrm{g} / \mathrm{ml}$ for B. subtilis against ampicillin as control at $20 \mu \mathrm{g} / \mathrm{ml}$, whereas $94 \mu \mathrm{g} / \mathrm{ml}$ for $E$. coli and $63 \mu \mathrm{g} / \mathrm{ml}$ for $K$. pneumonia against tetracycline at $20 \mu \mathrm{g} / \mathrm{ml}$ as control, respectively.

The plant has pinnatol as the chemical marker in the leaves; a trial was performed with stem bark of $P$. grandis for the presence of pinnatol in the stem bark to mimic the action of insulin. The study confirms the significant antidiabetic activity on the porcine pancreatic $\alpha$-amylase enzyme exhibiting the $\alpha$-amylase inhibitory activity. Among all the three extracts the ethyl acetate stem bark extract of $P$. grandis showed potent antidiabetic activity, and the $\mathrm{IC}_{50}$ value was found to be $40.42 \mu \mathrm{g} / \mathrm{ml}$.

This study may be proved to be an important step for the further study for identification, of compounds with the antioxidant, antimicrobial,

Table 4: In vitro antioxidant activity of Pisonia grandis by DPPH radical scavenging method

\begin{tabular}{llllll}
\hline Plant extracts & \multicolumn{2}{l}{ \% Scavenging activity } & & \multicolumn{1}{c}{ IC } \\
\cline { 2 - 5 } & $\mathbf{5 0} \boldsymbol{\mu \mathbf { g } / \mathbf { m l }}$ & $\mathbf{1 0 0} \boldsymbol{\mu g} / \mathbf{m l}$ & $\mathbf{2 0 0} \boldsymbol{\mu g} / \mathbf{m l}$ & $\mathbf{4 0 0} \boldsymbol{\mu g} / \mathbf{m l}$ & $\mathbf{8 0 0} \boldsymbol{\mu g} / \mathbf{m l}$ \\
\hline Hexane & 32.81 & 47.34 & 64.80 & 79.64 & 84.96 \\
Ethyl acetate & 42.25 & 53.27 & 66.03 & 78.23 & 83.91 \\
Ethanol & 47.79 & 60.22 & 70.65 & 78.03 & 85.22 \\
\hline
\end{tabular}

P. grandis: Pisonia grandis, $\mathrm{IC}_{50}$ : Inhibitory concentration ${ }_{50}$, DPPH: 2,2-diphenyl-1-picrylhydrazyl 
Table 5: Antimicrobial activity of Pisonia grandis by MIC method

\begin{tabular}{lllll}
\hline \multirow{2}{*}{ Strain } & \multicolumn{2}{l}{ MIC value $(\mu \mathrm{g} / \mathrm{ml})$} & & Ethanol \\
\cline { 2 - 5 } & Hexane & Ethyl acetate & 72 & 2 \\
S. aureus & 70 & 69 & 83 & $21^{\mathrm{A}}$ \\
B. subtilis & 60 & 54 & 94 & $22^{\mathrm{A}}$ \\
E. coli & 75 & 67 & 63 & $24^{\mathrm{B}}$ \\
K. pneumonia & 65 & 72 & $3^{\mathrm{B}}$ \\
\hline
\end{tabular}

Ref. drugs=A-ampicillin $20 \mu \mathrm{g} / \mathrm{mL}$, B-tetracycline $20 \mu \mathrm{g} / \mathrm{mL}$, S. aureus: Staphylococcus aureus, B. subtilis: Bacillus subtilis, E. coli: Escherichia coli, K. pneumonia: Klebsiella pneumonia, MIC: Minimum inhibitory concentration

Table 6: Antidiabetic activity of Pisonia grandis by $\alpha$-amylase inhibitory activity

\begin{tabular}{|c|c|c|c|c|c|c|c|}
\hline \multirow[t]{2}{*}{ Plant extracts } & \multicolumn{6}{|c|}{$\% \alpha$-amylase inhibition } & \multirow[t]{2}{*}{$\mathrm{IC}_{50}$ values $(\mu \mathrm{g} / \mathrm{ml})$} \\
\hline & $10 \mu \mathrm{g} / \mathrm{ml}$ & $20 \mu \mathrm{g} / \mathrm{ml}$ & $40 \mu \mathrm{g} / \mathrm{ml}$ & $60 \mu \mathrm{g} / \mathrm{ml}$ & $80 \mu \mathrm{g} / \mathrm{ml}$ & $100 \mu \mathrm{g} / \mathrm{ml}$ & \\
\hline Hexane & 12.38 & 33.92 & 47.10 & 65.80 & 70.41 & 74.61 & 39.46 \\
\hline Ethyl acetate & 12.21 & 30.24 & 56.30 & 60.12 & 69.23 & 70.12 & 40.42 \\
\hline Ethanol & 20.38 & 35.10 & 63.31 & 60.21 & 71.31 & 78.14 & 32.78 \\
\hline
\end{tabular}

P. grandis: Pisonia grandis, $\mathrm{IC}_{50}$ : Inhibitory concentration ${ }_{50}$

antidiabetic activities present in the stem bark of $P$ grandis for clinical use.

\section{CONCLUSION}

The results of the study revealed that different medically important phytochemicals were present in extracts of stem bark of $P$. grandis. This research has laid sufficient background for further study for identification, subsequent purification and isolation of compounds. The extracts possess antioxidant, antimicrobial, and $\alpha$-amylase inhibitory activity. Thus, the study has helped in establishing scientific evidences in the rationality of traditional use of plants for curing different human diseases. Hence, these findings will be useful toward establishing pharmacognostic standards on identification, purity, quality, and classification of the plant, which is gaining relevance in plant drug research.

\section{REFERENCES}

1. CSIR. The Wealth of India-Raw Materials. New Delhi, India: NISCAIR Publications and Information Directorate, CSIR; 1969.

2. Prabu D, Nappinnai M, Ponnudurai K, Prabhu K. Evaluation of woundhealing potential of Pisonia grandis R.Br: A preclinical study in wistar rats. Int J Low Extrem Wounds 2008;7(1):21-7.

3. Shubashini K, Sripathi SK, Poongothi G. Bioassay-guided fractionation and anti-fungal activity studies on Pisonia grandis. Iran J Chem Res 2010;10(9):35-7.

4. Shubashini K, Gopal P, Lalitha P. Allantoin from the leaves of Pisonia grandis. Int J Pharm Life Sci 2011;2(6):815-7.

5. Habibur R, Elumalai A, Chinna M, Dipankar B. Evaluation of anxiolytic activity of ethanolic extract of Pisonia grandis $\mathrm{R} . \mathrm{Br}$ leaves in mice. J Chem Pharm Res 2011;3(5):646-52.

6. Jayakumari S, Arthanareswaran A, Vijayalakshmi A, Malarkodi V, Ravichandran V. Free radical scavenging activity of Pisonia grandis leaves. Indian J Pharm Educ Res 2012;46(2):37-40.

7. Elumalai A, Chinna M, Habibur R. Pisonia grandis R.Br - A medicinal plant: A review. Int J Pharm Bio Sci 2012;3(1):76-80.

8. Sundaram R, Samuel J, Palavesam S. In vitro anti-plasmodial activity of chosen terrestrial medicinal plants against Plasmodium falciparum. Asian Pac J Trop Biomed 2012;2(1):252-6.

9. Elumalai A, Chinna M, Sindhura S, Rajendra D, Manikanta KV. Acute toxicity studies and antipyretic activity of a poly herbal formulation. Int J Biol Pharm Res 2012;3(1):130-2.

10. Majumdar A, Sahu M, Saraf S, Verma S, Yadav R. Evaluation of hepatoprotective \& anti-inflammatory activity of roots of Pisonia grandis R.Br. Planta Act 2012;2:141-7.

11. Elumalai A, Prakash G. Evaluation of anti-arthritic activity of ethanolic extract of Pisonia grandis. Asian J Pharm Res 2012;2(3):91-3.

12. Sharples JM, Cairney JW. Organic nitrogen utilization by an unidentified mycobiont isolated from mycorrhizas of Pisonia grandis. Myco Res 1997;101(3):315-8.

13. Anbalagan N, Rajinikanth KN, Kishore S, Thomas J, Bala K, Ramachandran S, et al. Analgesic, anti-inflammatory and diuretic activity of Pisonia grandis. Nat Prod Sci 2002;8(3):97-9.

14. Shubashini K, Lalitha P, Poongothai G. HPTLC fingerprinting of extracts of Pisonia grandis. Int J Pharm Sci Res 2011;9(1):180-3.

15. Poongothai G, Shubashini K. HPTLC method of quantitation of bioactive marker constituent pinitol in extracts of Pisonia grandis. Int Res J Pharm 2012;3(9):207-12.

16. Radha R, Arokiyaraj S, Agastian P, Balaraju K, Kumar RM, Bula P. Phytochemical analysis and anti-inflammatory activity of Pisonia grandis. Biomed Chem Sci 2011;2(2):193-9.

17. Kirtikar KR, Basu BD. Indian Medicinal Plants. $2^{\text {nd }}$ ed. New Delhi, India: International Book Distributor; 2008.

18. Elumalai A, Eswaraiah MC, Rahman H. Pisonia grandis R.Br - A medicinal plant: A review. Int J Pharm Bio Sci 2012;3(1):76-80.

19. Devi SS, Nandhini P, Himanshu T, Rajeswary H. Antioxidant activity of combined ethanolic extract of Pisonia grandis and Cardiospermum halicacabum. Int J Pharm Sci Rev Res 2016;39(1):95-100.

20. WHO. WHO-Quality Control Methods for Herbal Materials, World Health Organization-1211. Geneva, Switzerland: WHO Press; 2011.

21. Harborne JB. Phytochemical Methods: A Guide to Modern Techniques of Plants Analysis. $3^{\text {rd }}$ ed. London, UK: Chapman and Hall; 1998. p. 6-17.

22. Kokate CK. Practical Pharmacognosy. $4^{\text {th }}$ ed. New Delhi, India: Vallabh Prakashan; 2005. p. 1185-91.

23. Chang CC, Yang MH, Wen HM, Chern JC. Estimation of total flavonoid content in propolis by two complementary colorimetric methods. J Food Drug Anal 2002;10(3):178-82.

24. Vinod D. Pharmacognosy and Phytochemistry. $1^{\text {st }}$ ed. Nashik, India: Career Publication; 2003. p. 384-7.

25. Hamed MM, Mohamed AA, Ghareeb AM, Saleh SA. Chemical constituents, in vitro antioxidant activity, oral acute toxicity and Ld50 determination of Moringa oleifera leaves. Int J Pharm Pharm Sci 2017;9(5):240-7

26. McDonald S, Prenzler DP, Antolovich M, Robards K. Phenolic content and antioxidant activity of olive extracts. Food Chem 2001;7(5):73-84.

27. Chambers SM, Hitchcock CJ, Cairney JW. Ectomycorrhizal mycobionts of Pisonia grandis on coral cays in the Capricorn-Bunker group, Great Barrier Reef, Australia. Mycol Res 2005;109(10):1105-11.

28. Larissa ID, Arunachalam K, Fabio M, Ivana MP, Isanete GC, Sikiru OB, et al. Antimicrobial and antioxidant activities of selected plants used by populations from Juruena Valley, Legal Amazon, Brazil. Int J Pharm Pharm Sci 2017;9(5):179-91.

29. Dong YL, Heejung Y, Hyun WK, Sang HS. New polyhydroxytriterpenoid derivatives from fruits of Terminalia chebula Retz and their $\alpha$-glucosidase and $\alpha$-amylase inhibitory activity. Bioorg Med Chem Lett 2017;27(1):34-9. 